\title{
Settling Accounts with the Sultan: Cortesia, Zemechia and Venetian Fiscality in Fifteenth- Century Alexandria
}

\author{
Georg Christ
}

On the morning of the tenth of January 1420, four high-ranking Venetian merchants made their way towards the office of the Venetian consul, Biagio Dolfin, in the fondaco in Alexandria, Egypt. ${ }^{1}$ The four, Carlo Contarini, Lorenzo Bembo, Angelo Michiel, and Polo Michiel then proceeded to copy pages 45, 95 and 111 of the consul's ledger ('libro'). Each of them produced their own copy of these pages and each of them added a note specifying that they had done this on the behest of the consul. ${ }^{2}$ Such procedure seems unusual. Who were these merchants and what had happened? What was contained in the consul's ledger to motivate such solemn proceedings?

\section{Introduction}

Unlike the consular ledgers, which seem to be lost, these four copies survive. They contain excerpts from two accounts settling claims between the sultan al-Mu'ayyad Shaykh (r. 1412-1421) and the Venetian consul Biagio Dolfin (consul from 1418-1420) as well as between the sultan's customs inspector (Fakhr al-Dīn ibn Sufeir, in office $1415^{-25}$ ) and the Venetian community in Alexandria of the years 1418 and $1419 .{ }^{3}$ These accounts document transactions at the very

1 Many thanks to Jo Van Steenbergen, Malika Dekkiche and Kristof D'hulster for inviting me to the most inspiring international conference "Whither the Early Modern State? FifteenthCentury State Formations across Eurasia. Connections, Divergences, and Comparisons" in Ghent, 10-12 September 2014, where a first draft of this contribution was presented. Thanks also to Natalie Sharpin for thoughtful comments and Angela Marisol Roberts for elegant copy-editing.

2 "In Alexandria + MCcCCXVIIII a dì X zener e fo di maitina. Ad istanzia de miser Blaxio Dolfin consollo nostro, io Anzollo Michiel asieme con ser Lorenzo Bembo, ser Polo Michiel et ser Carlo Contarini fo de miser Iacomo, in la decima, in casa soa, al suo scriver", account copy A. Michiel, see for another version Appendix 1 of this chapter (end).

3 Christ, Trading Conflicts, on Biagio Dolfin pp. 97-110; on Fakhr al-Dīn p. 91 seq., on Venetians in Alexandria p. 95 seq. and passim. 
pulse of Veneto-Mamluk relations: the transit trade in spices. What do they tell us about Veneto-Mamluk relations and thus about the status of Venetians and Venice within the Cairo Sultanate or Mamluk Empire? Jo Van Steenbergen has recently discussed the problematic implications of the Mamlukization of late medieval Syro-Egyptian history, i.e. the tendency to interpret the multiple forms of statehood and power projection but also cultural expression, social life etc. of the Cairo Sultanate as 'Mamluk'.

Another facet of the 'Mamlukization' phenomenon is a tendency to reduce the range of the Sultanate's imperial policies to the centers of Egypt and Syria, Cairo and Damascus. While it is acknowledged that the Cairo Sultanate played a minor role in the Hijaz and in Nubia, the wider rim of the sultan's realm, also including Latin European powers, is often ignored. ${ }^{5}$ Veneto-Mamluk relations have been studied as bilateral relations between two a priori distinct and equal entities. Writing in a time of nation states, great scholars from Wilhelm Heyd to Eliyahu Ashtor thus tended to see these relations in a somewhat anachronistic way as bilateral agreements or treaties between independent states. ${ }^{6}$ The more recent study of Francisco Apellániz foregrounded fiscal elements and rightly interpreted these relations as a symbiosis or even Venetian exploitation rather than Mamluk oppression. ${ }^{7}$ Yet the impression thus remains bilateral and actual modes of integration, the peculiar arrangement under which Venetians did business in Alexandria not so much as members of a foreign nation state but as an integrated and integral part of the sultan's realm, remains underexplored. ${ }^{8}$

4 Van Steenbergen, “Mamlukisation"'. I will use the terms Sultanate or Cairo Sultanate (cf. the term Soldan del Chairo used in the Venetian accounts transcribed in the appendix) rather than 'Mamluk Empire' but retain the term 'Veneto-Mamluk' relations as a convenient shorthand and because of its widespread use in the literature. The term is, however, problematic as these relations connected the Doge (and to an extent his subjects, the Venetians, even somewhat including all Latin Christians) and the sultan rather than state-like entities as the term would imply.

5 Ibid., for an exception, see Dekkiche, "State Recognition in the Service of State Formation?" and also her thesis currently prepared for publication: Le Caire. Carrefour des Ambassades. She is currently in the process of extending her analysis to Mamluk policies with regard to European powers. On the Mamluk perception of other powers, see also Drory, "Maqrizi in Durar al-'Uqud with regard to Timur Leng"; Drory also gave a talk on the perception of European rulers in the same treatise at the 2013 CHESFAME in Ghent, which has not been published with the proceedings (cf. Vermeulen, D'hulster, and Van Steenbergen, eds., Egypt and Syria in the Fatimid, Ayyubid and Mamluk eras VIII).

6 Heyd, Histoire du commerce du Levant, p. 49: "traités de commerce"; Ashtor, Levant Trade, p. 27: "obtained an agreement", p. 68: "treaty".

7 Apellániz Ruiz de Galarreta, Pouvoir et finance en Méditerranée pré-moderne.

8 Cf. Christ, "The Venetian Consul". 
Veneto-Mamluk relations were, to a great extent, brokered locally and they were not understood only as bilateral but also--and importantly--hierarchical relations. The day-to-day negotiating occurred in Alexandria as these accounts clearly illustrate. The sultanic privileges carefully respected the prerogatives of local legal custom. The local negotiations, however, did not unfold in some sort of game-theoretical void but within an hierarchical imperial taxonomy. This order, although perhaps weak in its enforcement, was still very real in its diplomatic and legal consequences. The sultan, at least formally, did not negotiate with either the Venetian doge or his ambassadors. The sultan was the patron, perhaps mediator and, most importantly, supreme judge. He granted the Venetian privileges and thus protection and status and he spoke out against novelties that would jeopardize the established status quo. ${ }^{9}$

The Venetians did not interact with the sultan pari passu. Venetian envoys instead negotiated with officials of more or less equal rank. The sultan thence magnanimously heard the resulting proposal as a supplication and generously granted privileges that were expressed in unilateral administrative decrees directed to his subordinates. ${ }^{10}$ The preserved Veneto-Mamluk instruments are thus no treaties but decrees issued by the sultan. There was nevertheless an underlying contractual relationship, which formally consisted in the sultan's offer ( $\bar{y} \bar{a} \bar{b})$ of protection ( $a m \bar{a} n)$ and the Venetian acceptance (qabül) and submission to the sultan (șulh).. ${ }^{11}$ If the doge/the Venetians (in Alexandria) paid tribute to the sultan thus accepting the offer and submitting, Venice (concretely through the Venetians in Alexandria) came under his protection and thus became part of the Sultanate. Venice was thus removed from the dār al-harb and became as dār al-sulh part of the Islamic empire and thus the Sultanate. The Venetian status was thereby in some respects akin to the status of the Levantine Christian or Jewish communities (dhimma i.e. protected communities of the so-called people of the books, who [contrary to pagan 'idolaters'] had a defined and relatively protected status within the Islamic Empire). The inclusion of the Venetians, ingenuously, was even drafted as the inclusion of the entire (Latin?) Christian world by addressing the doge as "doxe glorioso, magnifico (...), lo honor de la generation de Yesu Christo, congregador de queli che adora la croxe, Doxe de Venetiani (the glorious, magnificent doge (...), the

9 Christ, "The Sultans and the Sea", p. 245.

10 Theunissen, "Ottoman Venetian Diplomatics", pp. 39 seq., 43. For a full list of the privileges, ibid. p. 40 and Pedani, "Gli ultimi accordi", p. 54 seq.

11 Șulh (from șalaha to do the right thing) basically meaning peace and reconciliation (after a state of conflict), Khadduri, "Șulh", in $E I^{2}$, pp. 845a-846a (also online s.v.); Theunissen, "Ottoman Venetian Diplomatics", p. 25 seq. 
TABLE 9.1 The Cairo Sultanate's system of unitary government and inclusion of Venice

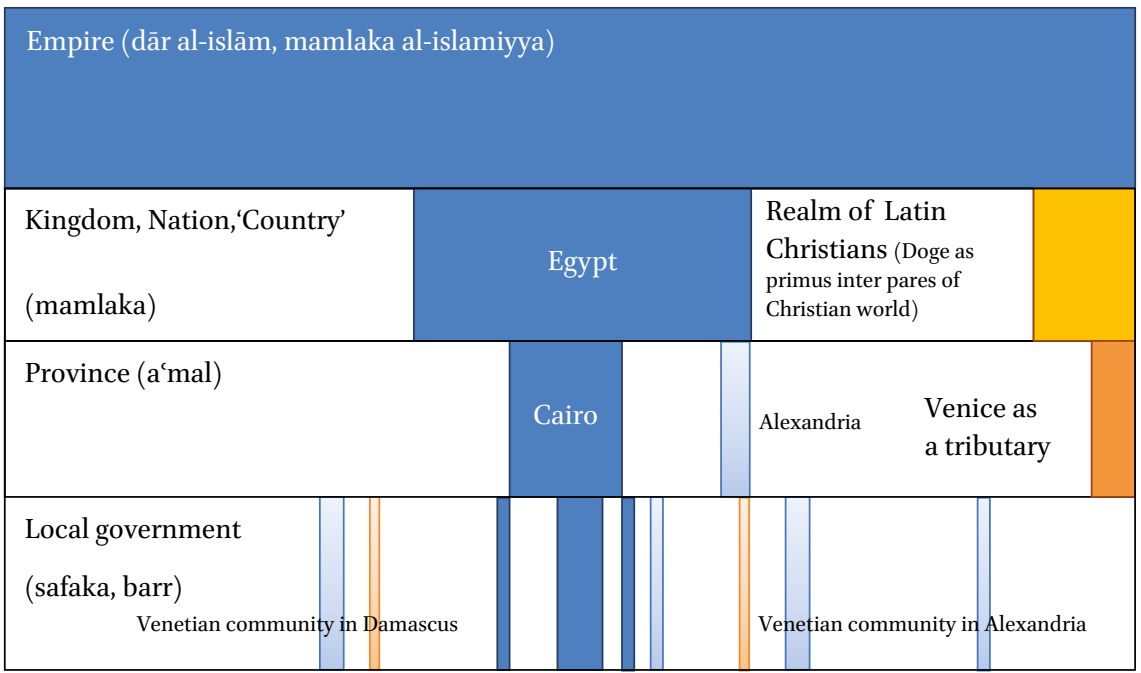

Blue denotes the sultanic, directly ruled realm, while light blue indicates fiscal prerogatives and delegation of power, e.g. over Alexandria. Orange indicates tributary relations such as those with the Venetian realm

honour of the generation of Jesus Christ, congregator of those who adore the cross, doge of the Venetians)".12 This bolstered the doge's status and perhaps helped to justify far-reaching privileges. The Venetians (and consequently by extension and legal precedence all [Latin] Christian merchants), thus, were (or could be) exempted from discriminatory measures technically applying to the regular dhimmi communities such as the ban to ride horses, discriminatory clothing or the payment of the jizya tax. Instead, the Venetians paid a special tribute partially documented by the accounts under investigation. ${ }^{13}$

Yet trade with the Venetians was not handled in Cairo under the eyes of the sultan, who delegated dealings with the Venetians to his representatives in Alexandria. There, players of roughly the same level locally brokered the concrete rules of the game as evidenced by the accounts.

I suggest an explanatory framework of multi-tiered imperial rule (table 9.1). It comprehends the Cairo Sultanate as a hybrid political entity, which partially and somewhat akin to a modern unitary authority conflates different tiers of government (blue). In the case of the Cairo Sultanate, this means the convergence of municipal/district, provincial, royal/regional and imperial/international rule in

12 Thomas/Predelli, Diplomatarium, p. 306.

13 See appendix. 
the person and the institutions of the sultan. Yet, and this is very different from the modern unitary body, the geographical boundaries of the different tiers or levels of government were not identical. ${ }^{14}$ The sultan's direct authority over the local/household and provincial level in many ways did not exceed the citadel and parts of Cairo. Royal or regional rule was claimed over parts of Egypt (blue). Islamic imperial claims theoretically covered a much wider area: the Islamic world and to an extent, with the sultan as an "Alexander of the present times", 15 even the entire oikumene (oikomene) or civilized world. What historical maps show as the Mamluk Sultanate, i.e. Egypt and Greater Syria, would be a de facto conglomerate (whereby rule over Syria was delegated) rather than a separate or 'official' tier.

I will thus consider the Cairo Sultanate as a conglomerate of large spaces around and relating to the imperial core of Cairo/Egypt. ${ }^{16}$ I take the sultan's rule to be construed as multi-tiered but with universal aspirations on the imperial level. The question is to which extent and how this rule materialized. What were the modes of imperial governance including the projection of power to places beyond the realm of the sultans' military control? I suggest that these spaces were hierarchically arranged and treated differently according to their function and their importance for the Sultanate. Rule over lower and middle Egypt as the core of the Sultanate had to be relatively direct (blue). Rule over areas in the wider realm of the Cairo sultanate including Upper Egypt and Syria was delegated (light blue), while rule over peripheral areas such as the desert borders, Red Sea, or the Mediterranean was left to tributary and more independent actors, such as Bedouin leaders, the sultans of Aden, Sharifs of Mecca or, last but not least, the Doges of Venice, who carried a whiff of royal rank (as some sort of primus inter pares of (Latin) Christians (orange)).

14 These boundaries are in any case blurred: see for the only partial/seasonal domination of the Hijaz, Meloy, Imperial Power, p. 234 and passim; for Anatolia: Wing, "Submission, Defiance, and the Rules of Politics"; Adriaenssens and Van Steenbergen, "Mamluk Authorities and Anatolian Realities".

15 Alexandro de questo tempo ("Alexander of this time"), one of the sultan's titles used in the privileges issued to the Venetians (Thomas/Predelli, Diplomatarium, II, p. 306).

16 "Large space" might evoke Schmitt, Völkerrechtliche Grossraumordnung, which was written in support of German expansionism leading to World War II. Besides its problematic ideological penchant (re-emerging today in the context of the Ukraine conflict), this concept is of but limited use in the Mamluk context as empire and world order are programmatically congruent, while Schmitt seems to advocate a multilateral imperial order, i.e. a world structured around a few competing empires or Grossräume, cf. Voigt, Grossraum-Denken. 
The graduations are, of course, somewhat arbitrary and the transitions are fluid: Ruling Cairo meant complex negotiations with many power brokers and delegation of much power. Indeed, delegation of power, at least formally, is the process of power devolvement that is tying together the various realms. For the sultan's power was fading not only in the imperial peripheries of the Red Sea area or the Mediterranean but also in some parts of Cairo. Thus power over a province or district near Cairo or over Syria was also delegated but more tightly controlled as (military) projection was regular and thus a plausible threat. The sultan's power, however, much less pervaded areas such as the Mediterranean, the Hijaz or the southern Red Sea area. He thus 'ruled' these areas via less controlled delegation characterized by a higher degree of negotiation. The delegation of power in the southern Red Sea to the Rasulid sultans, for instance, was largely a formal construction. ${ }^{17}$

The sultan, as it were, wore four hats: He was ruler of the faithful but also Alexander of his time and thus some sort of universal ruler (empire), ruler of (core-)Egypt (kingdom), mayor of Cairo (province) and, finally, head of his household and of his personal military units (local government).

Venice would thus be integrated into the sultans' realm in two ways. Indirectly and bottom-up Venetians were organized as autonomous, protected communities e.g. in Damascus and Alexandria. Directly and top-down were the tributary relations with the Doge as head of the Venetians.

Needless to say that this sketch (table 9.1) cannot capture accurately or holistically the complexities of the Sultanate's political structure. It is not a descriptive but an analytical model to analyse Mamluk-Venetian relations. ${ }^{18}$

After a few words on Venetian trade in Alexandria, I will briefly sketch the evolution of the institutional framework of Veneto-Mamluk relations with particular emphasis on two types of payments: the cortesia paid by Venetians to

17 Vallet, L'Arabie marchande, p. 516.

18 More layers would arguably have to be defined such as districts, the Sultanate's core lands vs. its Islamic tributaries etc. Also the distinction between dār al-Islam and dār al-harb might have to be considered more thoroughly. Then, of course, one would have to pay attention to the peculiarity of many pre-modern states (including, to an extent, today's England) which are characterized by the coexistence of different types of state finances, only partially to be separated from the ruler's finances (cf. the Roman fiscus and aerarium), which can complicate things considerably. Alexandria's revenues went to the dīwān al-khāsss, i.e. could be considered to be part of the sultan's demesne but it was not his private property (mulk), which typically would be protected against the grasp from future sultans/the state by being turned into religious foundations, cf. Ashtor, A Social and Economic History of the Near East, p. 318; Daisuke, Land Tenure, pp. 177-204; Loiseau, Reconstruire la Maison du sultan, p. 188 seq. 
local officials and the zemechia paid by the sultan to the Venetian consul. Against this backdrop I will analyze the evidence of the accounts under investigation and conclude by reviewing the hypotheses raised above.

\section{Background: Venetians in Alexandria and Fiscal Inclusion}

Alexandria had lost much of its ancient glory but was still the main port of Egypt in 1420. The global spice route had shifted south in the wake of the disintegrating Mongol Empire and a great deal of the trade with Indian spices, precious metal and cloth passed through Alexandria. For that reason, the town was teeming with diasporic trading communities of many nations and provenances. Prominent among them were the Venetians. The Venetian republic controlled a substantial part of the transcontinental spice trade in the Eastern Mediterranean and thus maintained a strong permanent presence with two fondachi (caravanserais) under the guidance of a consul assisted by a notary and a doctor. ${ }^{19}$

The Venetian nation in Alexandria had a great deal of discretion as to who would classify as Venetian for the purpose of belonging to their community or using its services including other Italians or colonial subjects, some of which were Jewish but also other Christian merchants. Some of these merchants visited Alexandria only very briefly for the month-long stay of the galleys but some remained for a much longer period and established more intimate commercial ties with their Egyptian counterparts and learned Arabic. As a result, ever changing coalitions of merchants, typically involving long-term residents in Alexandria (Venetian patricians, cittadini, some non-Venetians), well-heeled investors in Venice usually with some first-hand experience of Alexandria, merchants sent from Venice with the galleys and lower level intermediaries (colonial Venetians, other Italians, Egyptian Jews) operated in Alexandria and Cairo. ${ }^{20}$ The contribution of those coalitions to the Venetian community was double-edged. While they crucially bolstered trade by providing mediating services and insider knowledge thus facilitating communication between, say, customs inspector and the consul, they also undermined joint community action because they were in competition with one another. They, for instance,

19 Cf. Christ, Trading Conflicts; for Alexandria in general, see Labīb, "Iskandariyya"; also (yet not replacing Labīb's excellent survey), Leiser, "Alexandria (early period)" and Christ, "Collapse and Continuity: Alexandria".

20 See for example the coalition in which Angelo Michiel operated (Christ, "Beyond the Network"; idem, "Filippo di Malerbi", and idem, Trading Conflicts). 
tended to undercut attempts to form a Venetian pepper demand monopoly that could set a maximum price. By forming close business ties with Egyptian partners, they entered into a relationship based on long-term mutual obligations, which reduced the Venetian communities' freedom of action. ${ }^{21}$

The earliest preserved Venetian privileges for trade in Egypt date from the beginning of the thirteenth century. ${ }^{22}$ The Egyptian sultans regularly renewed the privileges upon Venetian request. ${ }^{23}$ The arrangements for the Venetians as emanating from the privileges are so advantageous that one must ask, to which extent they reflect a Venetian ideal rather than a reality. In fact, some practices like forced sales or taxes entered into the privileges only with a considerable lag if ever at all. ${ }^{24}$ The stipulations in 1415 are not significantly different from the earlier or later ones. They focus on full protection by the sultan included exemption from the ius naufragiis, exemption from inheritance tax/confiscation of intestate estates, exemption from regular Islamic jurisdiction, and the right to directly appeal to the sultan. They also confirmed the Venetian right to make use of two fondacos, freedom of movement across the entire empire and exemption from discriminatory measures imposed on local Christians. ${ }^{25}$

What perhaps mattered most to the Venetians were customs duties and other expenses. Yet the privileges mention them only marginally. In 1419, the officially stipulated tariff was of ten percent (de facto possibly lower), from which certain highly desired goods such as pelts or pearls where exempted, while gold and silver incurred a reduced tariff. ${ }^{26}$ The ushr, i.e. the tithe of ten percent seemed to increasingly have been accepted as an appropriate tax rate even for foreigners from the dār al-harb, ${ }^{27}$ while the customs in the Fatimid

21 Christ, Trading Conflicts, pp. 224-228; cf. Chap. XIII.

22 Tafel/Thomas, Urkunden zur älteren Handels- und Staatsgeschichte der Republik Venedig, vol. II, pp. 185-193.

23 Thomas,Diplomatariumvenetolevantinum, parsi; Thomas/Predelli,Diplomatariumvenetolevantinum, pars II; Pedani, "Gli ultimi accordi", p. 54 seq.

24 On the practice of Veneto-Mamluk trade, Ashtor, Levant Trade; on the conservatism of the privileges and their programmatic nature, Christ, King of the Two Seas.

25 Thomas/Predelli, Diplomatarium, Nr. 167, pp. 310 seqq. (1415), see also notes above. The exemption from being treated as a regular dhimmi would seem to be an advantage as it, for instance, meant that the jizya tax had not to be paid. On the other hand, however, the customs tariff on dhimmis would (at least according to the consensus of Islamic lawyers) have been only five percent, see Heffening, Das islamische Fremdenrecht, 54 seq.

26 Thomas/Predelli, Diplomatarium, Nr. 167, p. 311: osere $={ }^{c} u s h r$, i.e. a levy of ten percent, which was normal in this period (Sopracasa, Venezia e l'Egitto, p. 269); for possibly different procedures on the ground (with a provisional levy of only four percent on regular merchandise and one percent on gold and silver), see Christ, Trading Conflicts, p. 216. Heffening, Das islamische Fremdenrecht, p. 55 seq. 129; Labïb, Handelsgeschichte, p. 246. 
and Ayyubid periods (909-126o) had been 20 or even 30 percent. ${ }^{28}$ The privileges of 1238 indeed mention a quartum, ${ }^{29}$ that is 25 percent, which the Venetians attempted to lower. ${ }^{30}$ Francesco Balducci Pegolotti (fl. 1310-47), probably reflecting conditions in the 1320 ies, notes a tariff of 20 percent. ${ }^{31}$ The privileges, however, do no state a percentage but only emphasize the continuity of old custom. ${ }^{32}$ It seems that only in 1344 a Venetian envoy finally succeeded to lower the tariff to ten percent. ${ }^{33}$ Yet as we shall see more money was eventually supposed to flow to the Sultanate's leadership; not only to the sultan's treasury but to various receivers thus reflecting the Sultanate's system of de facto shared rule.

The sultans had always imposed other charges on the Venetians. Agents of the sultan, for instance, obtained a share of the pepper entering the Sultanate through the Red Sea. ${ }^{34}$ The Venetians subsequently had to purchase this pepper at a fixed price set above the market price. They had to accept it before they could buy pepper on the open market. This amounted to an additional de facto tax charged to the Venetian community. This practice most likely dates back to the late fourteenth century, the reign of Barqūq (r. 1382-89; 1390-99), but was

28 Labīb equates customs generally with the khums i.e. fifth of twenty percent, Labīb, Handelsgeschichte, p. $240 \mathrm{seq}$. reporting taxes for harbis of up to thirty percent, cf. also Cahen, "Douanes et commerce", p. 243 seq.

29 This interpretation is a conjecture: quartum, at least in the German medieval context, would mean a quarter of a set regular tax (for instance a quarter of the tithe to which the bishop is entitled), Deutsches Rechtswörterbuch (https://drw-www.adw.uni-heidelberg.de/ drw-cgi/zeige?index=lemmata\&term=Quart\#Quart-2.0 accessed 05.04.2020), s.v. Quart (II). Yet the present context would suggest that indeed the Arabic-Islamic khums is meant.

30 De hoc quod ipsi petierunt quod omnibus Veneti non abstolletur quartum, secundum quod fuit usum et morem. Unde precepimus ut dimittentur et non abstollentur (Mas Latrie, Traités de paix (1872), Supplément/Appendice, p. 72, II).

31 Pegolotti, La pratica della mercatura, xxi (dating), 72: Di ciò che metti in Allessandria all'entrare paga di diritto 20 per centinaio, e all'uscire paga niente.

32 Thomas, Diplomatarium, I, nr. 4, 7 cf. Sopracasa, Venezia e l'Egitto, p. 66.

33 Ibid., 292, nr. 154, cap. 1; also: Mas Latrie, Traités, Supplément/Appendice, p. 89, IX; Sopracasa, Venezia e l'Egitto, p. 267 seq.; Ashtor, Levant Trade, p. 67 seq.; cf. Venezia-Senato: Deliberazioni miste, vol. 9 registro XXII (1344-1345), §§ 351 seqq.

34 The provenance of the sultan's pepper cannot be studied in detail here. The pepper was probably collected as a customs levy in kind upon transit through the Red Sea ports and/ or Cairo (Ashtor, Levant Trade, p. 283; Heyd, Geschichte des Levantehandels, II, p. 448; Wiet, "Les marchands d'épices", p. 99), purchased by the sultan's agents in Jeddah or elsewhere or obtained as tribute from the Rasulids (Apellániz, Pouvoir et finance, pp. 70-79; Vallet, L'Arabie marchande, pp. 635-649; Vallet, "Du système mercantile à l'ordre diplomatique", [p. 8 of draft on academia.edu]). 
not yet inscribed into the privileges at this time. ${ }^{35}$ It was rooted in a practice of custom's staple right. This means the obligation to exhibit all imported goods in the customs area and to put it to sale on auction. The importer did not have to sell his goods to the highest bidder but could "outbid" them. Yet, consequently, he had to pay customs on the so established price. ${ }^{36}$ This was a sensible way for the customs administration to establish the price for the merchandise and thus to monetarize customs due by taking ad valorem. Alternatives were to levy the due percentage in kind (which entailed logistically complicated unpacking, quality control and weighing/measuring procedures) or fixed lists of monetary customs tariffs per unit of merchandise (giving rise to the genre of the tariffe manual navigating such procedures). ${ }^{37}$ In order to record these often controversial proceedings to establish the customs due, the Venetians had the right to have their own (Latin) scribe in the customs area. ${ }^{38}$

More importantly, not only the sultan was entitled to receive payments but also local interests although this naturally is not the particular focus of the privileges. They only vaguely allude to local custom and established practice. They summarily stated that no other payments than those thus prescribed were licit. These payments included a multitude of other dues, which could not be clearly separated from service charges. Venetian tariffe manuals for Alexandria list these charges in detail for each type of merchandise. Among them figure two types of payment which archival sources show to be particularly contentious: the manzaria (also tome, Arabic tuma, i.e. food expenses) and the cortesia, lit. "politeness", as some sort of institutionalized tip. Both of these payments were not due to the fisc or another institutional treasury but to local actors whereby it remains ambiguous to which extent they were ad personam or ad officium. . $^{39}$

The merchant selling/importing or acquiring/exporting paid their taxes individually. The purchase of sultan's pepper and related cortesia payments, however, required communal action and communal funds. The accrual and

35 Christ, King of the Two Seas; Ashtor, "Le monopole de Barsbay", p. 553 seq.; Vallet, Arabie Marchande, p. 644.

36 Mas Latrie, Traités, Supplément/Appendice, p. 74, II (1238) cap. 5: mercimoniarum que incantantur in doana, quando finitur incantacio, si dominus vult dimittere in doana vel accipere supra se ad vendenum in civitate, habeat potestatem vendendi, cf. p. 78, IV (1254), cap. 10.

37 Alessio Sopracasa shows in his most punctilious and diligently introduced edition that, in the late fifteenth century, the evaluation of the merchandise was a procedure separate from trading, although the customs administration remained also a market place, Sopracasa, Venezia e l'Egitto, pp. 271, 374 seqq.

38 Mas Latrie, Traité, Supplément/Appendice, p. 75, II (1238), cap. 22.

39 Christ, Trading Conflicts, pp. 150-153; Sopracasa, Venezia e l'Egitto, p. 289 seq. 
management of these funds necessitated a stable and permanent Venetian institutional presence and a Venetian fiscal system or treasury in Alexandria. These funds would also cover other expenses relating to Venetian trade in Alexandria, e.g. maintenance and running of the fondacos, the scribe at the customs, the notary etc. ${ }^{40}$ The Venetian fiscal system was composed of two different funds alimented by different taxes. The cottimo alimented the communal fund and the consolazio the consular cash box. ${ }^{41}$ The extracts under investigation document the cash-flow in these funds.

The Venetian fiscal system in Alexandria was institutionalized only gradually. While the privileges from the early thirteenth century seem to indicate that the consular office was either not permanent or, more likely, that the consuls were not regularly residing in Alexandria for the whole year, ${ }^{42}$ the Venetian Senate stipulated that the consul should stay for two years in Alexandria in $1271 .{ }^{43}$ From the year 1284 survive the instructions to such a resident consul. ${ }^{44}$ In 1302, the privileges summarily noted that the Venetian consul could officiate according to established legal custom (consuli Veneciarum fiant consuetudines).${ }^{45}$ Although interrupted by a resurgence of crusading fervour from 1309 until 1344 and again, briefly, from 1367 to 1372, the institutionalized Venetian presence embodied by the consul essentially became permanent. ${ }^{46}$

The sultan provided part of the consul's income. The accounts under investigation evidence that this payment, the zemechia (clearly meaning jamakiyya, i.e. a stipend for a mamlük), was not paid in cash but deduced from the payments due to the sultan. As such a deduction, the contribution dates back to the origins of the permanent consular office in the mid-thirteenth century. ${ }^{47} \mathrm{It}$

40 According to the privileges the Mamluk authorities maintained the fondaco, but in practice this was (at least sometimes) not the case, Christ, Trading Conflicts, p. 72.

41 Christ, Trading Conflicts, pp. 77-88.

42 Mas Latrie, Traités, Supplément/Appendice, p. 74, II (1238), cap. 8, et si ibi non fuisset consul, cf. p. 78, IV (1254), cap. 14, cf. cap. 20.

43 Jacoby, "Les Italiens en Egypte", p. 83.

44 Jacoby, "Le consulat vénitien d'Alexandrie".

45 Thomas, Diplomatarium, nr. 4, p. 6, cap. 7.

46 Ashtor, Levant Trade, p. $55^{1}$ seq., Christ, "Kreuzzug und Seeherrschaft"; id., "Non ad caudam".

47 Mas Latrie, Traités, Supplément/Appendice, p.79, IV (1254) first as the right to import freely (for the value of?) 2000 bezants: Consulem: ipse sit francus de bizanciis mille annuatim. Assuming a tariff of twenty percent this would amount to 400 bezants. If we interpret it more restrictively as the right to import gold freely it would amount to less as gold was paying a lower tariff (at the beginning of the fourteenth c.) of four percent according to a decision of the Venetian senate published in Sopracasa, Venezia e l'Egitto, p. 268; cf. Thomas, Diplomatarium, I, p. 6 (1302), p. 294 (1345); II, p. 170 (Damascus 1375: el consolo di Veniciani diebia aver al anno bisanti duxento d'oro, i qual se intenda de le marchadantie che li 
first appears under the name zemechia in the privileges granted by sultan alMu'ayyad Shaykh (r. 1412-1421) shortly before the drafting of our accounts in $1415{ }^{48}$ This seems to be in line with the trajectory on which the Persian term jämakiyya enters through the Seljuq realm (where it meant remuneration in cloth) to the Cairo Sultanate. There it first meant the salary of a mamlük in a clerical function by the beginning of the fourteenth century. By the end of the fourteenth century, it meant a monthly, monetary stipend granted by the sultan to his personal mamlūks. ${ }^{49}$ This money was paid by the ustädār or another high official, later even in the presence of the sultan, in the citadel..$^{50}$ Yet while the mamlüks received around 80 dinars a year, the Venetian consul could claim first a thousand and later, probably since 1365 , still two hundred dinars. ${ }^{51}$

The Venetian custom system and in particular the zemechia payment reflect the close integration of the Venetian community (and by extension Venice) into the Sultanate as a very generously privileged dhimma community. The consul is thereby quasi conceived as a sultanic official as evidenced by the zemechia payment. ${ }^{52}$ The following section will analyze the accounts documenting the financial underpinnings of this arrangement and explore how they shed light on the relations between the sultan and the Venetians.

Turning to our main source, we note that although the four extracts from the consul's accounts vary considerably in detail, they match as far as the essentials of the transactions (corresponding accounts, actors, and amounts) are concerned. They are kept among the papers of the Venetian consul in Alexandria, Biagio Dolfin d. 1420, in the archives of the Procuratori di San Marco, in the State Archives of Venice. ${ }^{53}$ They are all written on the commonly used

marchadanti porta a, Damasco; zoè al dretto che li paga, et cossì commanda messer lo Soldam).

48 Thomas/Predelli, Diplomatarium, II, p. 313 (1415: che queli habia prouision over zimichia dala doana); cf. p. 325 (1422: zemechia da la doana).

49 Monés, "Djāmakiyya".

50 Ayalon, "The System of Payment", pp. 50-56.

51 Ibid., p. 55, for the amounts owed to the consul see the account in the appendix.

52 Cf. Christ, "The Venetian Consul"; also in Latin early modern Europe a permanent resident was perceived as a sign of a close union between the sending and receiving states (Mattingly, Renaissance Diplomacy, pp. 95, 154).

53 How did the accounts endup among Biagio Dolfin's private papers? The copies must have been given back to the consular archive by the Venetian officials copying them after the aborted mission to the sultan (see below). Lorenzo Dolfin, nephew and heir of Biagio, 
imported paper (produced by a mill in the Veneto) of roughly A3 (double-folio) format. In some cases, only a half sheet is used. The documents are written with ink in a Venetian late-gothic half-cursive or mercantesca, whereby readability and conventions (abbreviations, Latin or Arabic numbers) vary considerably. ${ }^{54}$ The papers are slightly damaged by damp stains but are readable with the help of an ultra-violet Wood lamp. For the purpose of this analysis, I use the copy by Polo Michiel as the principal reference and refer to the other copies for clarification. ${ }^{55}$

The account is part of a system of double-entry venture accounting (bookkeeping) evidenced by the regular references to other pages of the ledger containing personal, expense and real accounts. ${ }^{56}$ The left-hand column lists debits: die dar and the right-hand column credits: die aver. The copies contain extracts from three different but corresponding personal accounts: no. 45 of the sultan and nos. 96, 111 of the customs inspector in Alexandria. ${ }^{57}$ The account extracts run over two pages of the same (double-)folio.

The first account (no. 45 of the consular ledger) starts with the consul debiting himself with the zemechia. On the credit side the sultan's alleged debt of 200 bezants, here equivalent to 200 dinars, is matched only by two payments by the customs inspector to the consul via the Venetian dragoman Obed of 50 and $5^{8}$ dinars respectively. The account is not balanced as it was still an active account at the time the copies were drafted.

The next account (extracted from no. 96 of the consular ledger), although formally the customs inspector's account, in fact records transactions with all three representatives of the sultan in Alexandria, who were involved in the handling of the sultan's pepper: the so-called chadi nadro della doana, the cus-

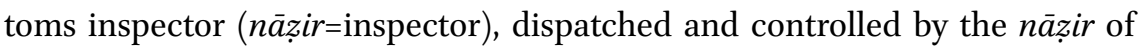
the dīwān al-khāsș (the sultan's demesne or personal treasury); the amìr (governor) of Alexandria reporting arrival of ships and probably also an estimate of

returned to Venice shortly after his uncle's untimely death. He must have taken with him all papers of his uncle he could put his hands on without being able or willing to separate private from official documents. It was all evidence against the many (some rather obviously fraudulent) claims on Biagio's estate. Originally, the papers of Biagio Dolfin were part of the archive of Lorenzo Dolfin and re-classified as a separate estate/archival entity only in the 2oth century, cf. Christ, Trading Conflicts, pp. 6-13.

54 The most hastily drawn copy is by Carlo Contarini, see Appendix 1; on the further career of Carlo Contarini as vice-consul upon Biagio Dolfin's departure to and subsequent death in Cairo see Christ, Trading Conflicts, pp. 223, 231 seq., 277-279.

55 See Appendix 1, below; variants are indicated in footnotes; see below notes $64 \mathrm{seq}$. for the identity of the four merchants, who produced copies.

$5^{6}$ Lane, "Venture Accounting”; also Melis, Storia della ragioneria, 439 seq.

57 See Appendix 1. 
the cargoes; and the sultan's merchant delivering the sultan's pepper. ${ }^{58}$ In all but Carlo Contarini's copies, this account is struck out and in all four copies the balance is drawn and carried forward to the verso, which is the continuation of the customs inspector's account (no. 111 in the consular ledger). As in the case of the sultan's account (no. 45), this also is stylized as a personal account debiting received money and crediting given money (i.e., in this case, incurred fiscal obligations). The payments received by the customs inspector are listed on the debit side. They include 6oo ducats from the consular cash box (chassa de conto), ${ }^{59}$ minor payments by another Venetian merchant and a more substantial payment valuing 680 Bezants by the consul through his nephew (i.e. not accredited to the consular cash box but to Lorenzo Dolfin's personal account). The credit side lists the monetary equivalents of the "services" to be rendered by the customs inspector. The first entry states rather bluntly: "Chadi nadro [di doana] de aver che lifo promesso di darli s'el se portasse ben in [lo fato del] romper di la voxe del piper duc. 6oo d'oro (Customs inspector to be credited 600 ducats that were promised to be given to him if he behaved well in the breaking-up [concluding] of the pepper voce [auction of the sultan's pepper])".60 The account goes on listing payments to the customs inspector which were all effected in the context of the forced purchase of sultan's pepper through an auction (voze, voxie) whereby it becomes clear that there were two auctions (which was unusual).

It is worth noting how these transactions relate to other accounts. The brokers' fees, which, apparently, were paid via the customs inspector, are debited to the brokerage account, apparently a separate fund, which had to be cleared by the merchants. A payment to the amir of Alexandria is classified as cortesia (courtesy), i.e. some sort of customary bribe/tax, and thus debited to the cotti$m o$, the Venetian communal fund. A similar cortesia payment to the customs inspector in the context of the pepper auctions is also debited to the same fund.

The copies of the two accounts extracted from the consular ledger thus highlight not only the importance and considerable financial implications of absorbing the sultan's pepper but also how center and periphery were intertwined. The sultan has a separate account. Yet the extraction of his account together with that of the customs inspector and the dominating theme of auctioning the sultan's pepper clearly connect the two. The Venetians must have seen the sultan as ultimately responsible for the actions of the customs

$5^{8}$ Christ, Trading Conflicts, p. 236, in general Chap. XIII.

59 Usually called conto di cassa (Melis, Storia della ragioneria, p. 439).

6o See Appendix 1. 
inspector. They probably planned to address the sultan as the supreme ruler whose foremost task was to "erect justice among mankind"61 to redress the balance of payments and thus re-establish justice. What had happened to necessitate this? What were the perceived injuries that occurred during the pepper auctions?

\section{Future Trading, Punitive Pepper Auction and Venetian Appeal to} the Sultan

It is clear that the accounts relate to the two auctions of sultan's pepper forced onto the Venetian community. The customs inspector obviously played a crucial role in it. Looking for other documents of the same month, we find a deliberation taken by the Venetian community's council, the Council of Twelve, on 7 January 1420 , which is three days before the copies of the two accounts were produced. It was decided to send a delegation to Cairo in order to submit a formal complaint to the sultan regarding the above-mentioned two pepper auctions. ${ }^{62}$ Some Venetians obviously felt that the customs inspector had treated them unfairly and meant to use the excerpts from the consular ledger as evidence against him. The four merchants drafting the four copies were the highest-ranking members of this council; some sort of executive committee. Their names rank first in the list of attendees opening the deliberation, two of them (Angelo Michiel and Lorenzo Bembo) appear in other documents as consiglieri (councilors), i.e. heads of the council, and Carlo Contarini was the viceconsul, who had to replace the Venetian consul Biagio Dolfin while he was absent from Alexandria or in case he died in office. ${ }^{63}$ Polo Michiel, another important merchant and possibly a relative of Angelo Michiel, was together with Lorenzo Bembo elected to accompany the consul on his trip to Cairo to submit the official complaint to the sultan. ${ }^{64}$

61 Suscitador de zustixia in la humana generation, acordador e mezador entro queli che a torto e raxon, privilege of 1415, Thomas/Predelli, Diplomatarium, II, p. 306.

62 Decision of the Council of Twelve, about the prices for pepper, Alexandria, 7 January 1420. 07.01.1420, Asve, Procuratori di San Marco, Commissarie miste, b. 180, "Comissaria Biagio Dolfin", fasc. III, f. 4.

63 Ibid. and Christ, Trading Conflicts, pp. 223, 231 seq., 277, 279.

64 Polo Michiel, rather than the naturally predestined councillor Angelo Michiel, was probably selected because the latter was too heavily involved in the future trading at the heart of the problem, which meant a conflict of interest, Decision of the Council of Twelve, Alexandria, 7 January 1420, Asve, Procuratori di San Marco, Commissarie miste, "Comissaria Biagio Dolfin”, b. 18o, fasc. III, f. [4], for A. Michiel's future trading, see Christ, "Beyond the Network". 
What had happened to trigger two auctions (rather than the usual one auction) to distribute the imposed sultan's pepper? What triggered additional payments to the inspector? Over the summer of 1419 , Venetian merchants had engaged in risky future deals regarding the expected amount of Indian pepper bound to arrive in Alexandria during the Nile flood in late summer and autumn. One of these deals involved a merchant of the sultan, who was tasked to deliver the sultan's pepper to the Venetians (and perhaps other merchant communities) in Alexandria. At the same time, the consul, buttressed by a solid majority of the Council of Twelve and thus, arguably, the Venetian community, forbade these speculative practices. He negotiated a very sensible price of 150 bezants per sporta for the sultan's pepper (market price: ca. 150-16o) with the customs inspector, who was responsible for the processing of the respective payment to the sultan. This support, however, came at a hefty price as indicated in the accounts. As it turned out, the consul and his supporters were right in distrusting the high expectations of the future traders. The latters' anticipated pepper price of 200 bezants was much higher than the actual prices paid when the Venetian galleys arrived in Alexandria in October 1419. When the customs inspector learned of the future trades and the anticipated high price from the sultan's merchant (who was involved in the future trade himself) he felt cheated. The future price of 157 dinars contrasted sharply with the negotiated dumping price and thus undermined his position with respect to his superior in Cairo. He consequently raised the price for the sultan's pepper already processed (of the first auction) and imposed a second load of pepper at 170 bezants (second auction) to be distributed among the members of the Venetian community. ${ }^{65}$

Although the consul worked out a solution with the customs inspector (and a sensible one as the consul argued emphatically in a long letter to the Senate), ${ }^{66}$ some merchants felt hard done by and lobbied the senate in Venice as well as the Council of Twelve in Alexandria. Eventually this pressure forced the consul into a mission to Cairo in order to redress the locally negotiated solution. It is obvious that the customs inspector's account was essential in the planned appeal to the sultan. Why, however, was the sultan's account included? This account, as we have seen, regarded the zemechia, i.e. the regular stipend received by the consul as a nominal member of the Sultanate's system of government. The main reason for the inclusion is that the zemechia had to be

65 On this episode, ibid., 229-249 (Chap. XIII).

66 Ibid., Chap. XIII, letter in the appendix 317-327. 
paid from the customs levied by the customs inspector. ${ }^{67}$ It might have insinuated a further accusation; that the customs inspector pocketed the money due to the consul.

Furthermore, the zemechia featuring prominently at the head of the document reminded the reader of the distinguished rank of the consul; that he was part of the Sultanate's courtly taxonomy. It looks almost like some sort of ID, an entrance pass, to facilitate access to the sultan. The key elements connecting the two accounts were courtly payments. That is what cortesia originally meant and the zemechia would then appear as some more formalized form of a cortesia owed to the consul. Hence, the alleged non-payment of the zemechia (by the sultan through the customs inspector) contrasted with an alleged overpayment of cortesia (to the customs inspector and his men). This formed a powerful argument and the way of presentation as meticulously drafted accounts presented it with a captivatingly rational and transcultural touch of fiscal sophistication. For accounts were not only a Venetian feature and in line with the Serenissima's corporate identity and the tone of voice of a merchants' republic. They were also part of the administrative and courtly culture, of statesmanship, of an Islamic empire. ${ }^{68}$ The minus of courtesy from the Sultanate's side further emphasized the surplus of the Venetians, who not only duly paid but over-paid their dues.

How the Venetian delegation to Cairo intended to deal with the trickier issue of the obvious Venetian attempt to dump the price of the sultan's pepper and the forward purchases/future speculations, which were at odds with not only Venetian regulations but also Islamic law, we probably will never know. We do know, however, that the appeal to the sultan, i.e. the attempt to overturn local arrangements by appealing to the imperial power, was unsuccessful. An epidemic was ravaging Egypt at the very time the delegation took off to Cairo, and while the consul died in Cairo, one of his main witnesses died in Alexandria. ${ }^{69}$ The consul's official successor came late enough to eschew the obligation to renew his late predecessor's efforts. The particular circumstances in early 1420 might explain this: less pepper was available in Alexandria and thus more expensive due to political problems in Aden and harsh taxation in

67 This becomes clear from the context of the privileges of 1422, Thomas/Predelli, Diplomatarium, II, p. 325, cap. XIV: i consoli de Dimasco, che quelli habia provision over zemechia da la doana, segando la quantitade che ha el consolo d'Alexandria, e de questo si fa testemonianza le tariffe de le doane, et in questo tempo non vien resposo al dicto consolo de la zumechia (sic).

68 Hinz, "Das Rechnungswesen”; cf. Labīb, Handelsgeschichte, p. 235. Vallet, "La comptabilité d'État".

69 Christ, Trading Conflicts, p. 279; Christ, "Filippo di Malerbi". 
Jeddah, ${ }^{70}$ while the conflict between Venice and King Sigismund (r. 1387$\left.{ }_{1437}\right)^{71}$ and war in France reduced demand and thus the urgency of addressing the situation in Alexandria. ${ }^{72}$

Hence Venice and Cairo did not revise the locally brokered solution. The accounts nevertheless document that the regulatory framework of appeal propagated by the privileges was felt to be a possible if difficult option. Recourse to it was attempted although it ultimately failed.

\section{Conclusions: Imperial Order and Local Arrangements}

The Sultan's zemechia and the Venetian cortesia as two different yet similar types of payments are joined in the accounts under investigation to formulate a powerful complaint against one of the local Egyptian interlocutors of the Venetian community in Alexandria. The complaint is formulated in the dry common language of fiscal accounting. It is not arguing for a change of the status quo. It is not even accusing. It merely asks the supreme judge to support them and to redress the balance; to settle an account and thus to do justice.

The Venetian state's representative, the consul in Alexandria, was integrated into the Sultanate's taxonomy via nominal inclusion into the court through the zemechia. This inclusion is reflected on the diplomatic macro-level (privileges) by the diplomatic strategies deployed to include the Venetian doge and state into the Cairo Sultanate, including embassies, gift exchange, tribute payments and the narrative style of the safe conducts or commercial privileges. ${ }^{73}$

The embassy, for which these accounts were drawn, did not manage to gain access to the sultan. Hence, we can only speculate what the sultan would have done. Probably not much, for we do know that a few years earlier, in the case of a similar grievance, the sultan made it very clear that he did not want to be directly involved in the nitty-gritty problems of trade in Alexandria. While he emphatically confirmed his basic commitment to protect the Venetians (amān), he relegated the resolution of the concrete issue to the governor of Alexandria. ${ }^{74}$ The Venetians, essentially, had to come to terms with the local powers: the amir and the customs inspector. The consul, therefore, received

70 Vallet, Arabie Marchande, p. 653 seqq.; Christ, "Beyond the Network", p. 40 (referring to the situation in summer 1419).

71 King of Hungary since 1387 , king of the Romans 1411.

72 Christ, “Passagers clandestins?", p. 282; Christ, Trading Conflicts, p. 200.

73 Cf. Christ, "Masked Cooperation with the Infidel?".

74 Translation of a safe conduct of the Sultan to the Venetians, 9 April 1418, ASve, Procuratori di San Marco, Commissarie miste, b. 18o, fasc. IX, f. [1]. 
local officials in the fondaco and administered regular cortesia payments. ${ }^{75}$ And, in more or less flagrant violation of sultanal privileges and Venetian regulations alike, some merchants established special relations to Egyptian officers both locally and in Cairo. They established and maintained these ties through business relations and generous gifts (often of cloth thus perhaps echoing or even quoting the sultanic custom of bestowing honorary robes - and to which also the zemechia, in its original meaning, referred ${ }^{76}$ ).

The resulting image is thus one of Veneto-Mamluk trade relations under a hybrid institutional framework, which was negotiated locally but in the shadow of imperial, sultanic privileges. The imperial order, as a system based on the delegation of power, recognized and buttressed local arrangements. Locally reached consensus, tested over time, could become customary and thus more or less explicitly protected by the privileges' tireless emphasis on established custom (e.g. in the 1415 privileges: segondo che se contien in le uzanze e paxe antique). ${ }^{77}$ If such rules, however, were renegotiated and produced new rules, there was a window of opportunity during which one could challenge it as $b_{i d}{ }^{c} a$ (novelty; a problem to orthodox Islamic law) ${ }^{78}$ as the privileges clearly state: non i sia innovà vsanza nuova ("there should not be innovated [any] new custom [as in: customary law]"). ${ }^{79}$ The cortesia payments as such were perfectly legitimate. They were the necessary lubricant, a catalyzer to facilitate the finding of consensual solutions to new problems, to bridge the gap between established procedures and unforeseen or unregulated problems. Such solution could occur ad hoc, on a case-to-case basis, without further consequence. Solutions also could slowly become established as standard procedures and thus become legal custom. In the grey zone between the two, there was room to denounce a new solution and the connected payments as innovation- so in this particular case of future trade and the respective punitive action.

The accounts were copied precisely with the intention to explore this ambiguity and to launch an appeal to the sultan. An unsettled account of mutual courtesies was to be brought to the court, to the sultan as the ultimate judge. The juridical and perhaps more importantly social (feudal) framework within

75 Christ, Trading Conflicts, pp. 74, 237 for receiving of officials and appendix for cortesia payments.

76 On gifts of cloth to Mamluk officials, see Christ, Trading Conflicts, p. 8o: on honorary robes: Petry, "Robing Ceremonials in Late Mamluk Egypt"; Mayer, Mamluk Costume, Stillmann, "Khil'a"; Walker, "Rethinking Mamluk Textiles"; Springberg-Hinsen, Die Khil'a; Diem, Ehrendes Kleid und ehrendes Wort.

77 Thomas/Predelli, Diplomatarium, II, p. 312.

78 At-Turkumānī, ed. Labīb, Kitāb al-Luma; Labīb, "The Problem of the Bid'a".

79 Thomas/Predelli, Diplomatarium, II, p. 310. 
which trade was supposed to unfold was (although essentially localized on the micro-level) cast in and buttressed by the interconnected and complementary (sultanic) imperial and (Venetian) state regulations on the macro- and mesolevels, grounded in the integration of the Venetians, of Venice, into the sultan's and thus Islamic realm. The resulting regulatory framework served as a fallback position. The imperial and stately shadow was powerful enough to influence and delimit arrangements shaped locally.

The accounts seem to illustrate a type, or, rather, phase of statehood, in which the government, that is here the sultan's personal treasury or fisc, vigorously attempted to assert direct control over the financial revenues of Alexandria and, hence, transit trade. ${ }^{80}$ Such control, however, could only be achieved to a very limited extent as the strategy of doing so was based, and could only be based, on the principle of divide and rule. The sultan delegated power to and thus shared power with his subordinates, including the doge of Venice and the Venetian consul in Alexandria. This power sharing arrangement, de facto leading to a deployment of power to the local/micro-level, was brokered within the framework of (sultanic) imperial rule, officially asserting far-reaching imperial control, on the macro-level. The inclusion of Venice and the Venetian consul into the Sultanate's imperial order, although first and foremost symbolical, was far from being meaningless for the merchants operating on the ground. Accounts, carefully documenting zemechia and cortesia payments, connected the financial flows between Venetians and the sultan. They evidence how arrangements responding to the economic logic of supply and demand were brokered locally and horizontally between actors of similar status. Yet this happened in the shadow of an imperial realm emphasizing the vertical power differential and tributary contract between the "Doxe glorioso, magnifico e de gran autorità (the glorious, magnificent Doge of great authority)" who submitted to the sultan, the "spada del mondo e de la lè, (...) Alexandro de questo tempo, semenador de zustixia e de bontà (the sword of the world and the law, (...) Alexander of this time, sower of justice and goodness)".81

8o This should not be interpreted as a transformation towards some sort of fiscal military state. Egypt has been a fiscal military state for a very long time. The only thing that perhaps changed was a stronger emphasis on customs dues to compensate for declined regular tax revenue, cf. Christ, King of the Two Seas.

Thomas/Predelli, Diplomatarium, II, p. 306. 


\section{Appendix 1: Document}

This is the transcription of accounts settling claims between the Venetian community in Alexandria and the Sultan/customs inspector, copied from the consul's ledger by Polo Michiel (P.M.) on the morning of 10 January 1420, Asve (Archivio di Stato, Venice), Procuratori di San Marco, Commissarie miste, "Commissaria Biagio Dolfin", b. 181, fasc. XXIII, int. n, f. [9]. It is an example of what Lane would call Venetian venture accounting. ${ }^{82}$

The transcription used other copies of the same accounts mainly by Angelo Michiel (A.M.), b. 181, fasc. XXIII, int. n, f. [5], without systematically indicating minor variants in the other copies. ${ }^{83}$ Variants are set in square brackets (mainly parts omitted by A.M.) or footnotes. The word or abbreviation preceding the number indicating the reference account is universally rendered as "c". for conto. ${ }^{84}$ All Roman numerals are reported in Arabic numerals for convenience, although in the originals dates, most amounts in the textual entries, and crossreferences to other accounts are reported in that form, while the sums on the right of each column are in Roman numerals.

While the payments are often effected in ducats and sometimes perhaps in silver currency, the money of account used is the (ideal) gold bezant, which is equal to the ideal or canonical dinar (but different from the real-existing coin called bezant minted at the same time in Byzantium), rather than the pound (Lira $£$ ) and subdivisions used in Venice. This might be inspired by the traditions of Islamic imperial fiscal accounting converting payments into gold dinars. ${ }^{85}$ The bezant (here abbreviated throughout with bx.) is divided into 24 carats (k.) and each carat into 6 parvoli (p.). The (ideal) ducat (duc.) was technically of the same value but real-existing ducats mentioned in the accounts are worth slightly less (because of wear and tear but also clipping). Therefore, they were valued at a rate slightly lower than the ideal bezant/dinar in these accounts, at $22.125 \mathrm{k}$.

For a reconstruction of the part of the consul's accountancy covered here see, Appendix 2 below; for the diplomatic description of the document see above in the main text.

\footnotetext{
82 Lane, "Venture Accounting".

83 The copies by Carlo Contarini (C.C.: ibid., b. 181, fasc. XxiII, int. n, f. [10]) and Lorenzo Bembo (L.B.: ibid., b. 181, fasc. XXIII, int. n, f. [6]) are more difficult to decipher on account of their handwriting and damp stains but clearly converge with P.M.

84 'h' (P.M., L.B.: maybe as in hoc the same [ledger]), 'lo' (?) (C.C.), 'ct' (?) as in conto? (A.M.).

85 Hinz, "Rechnungswesen", p. 9.
} 


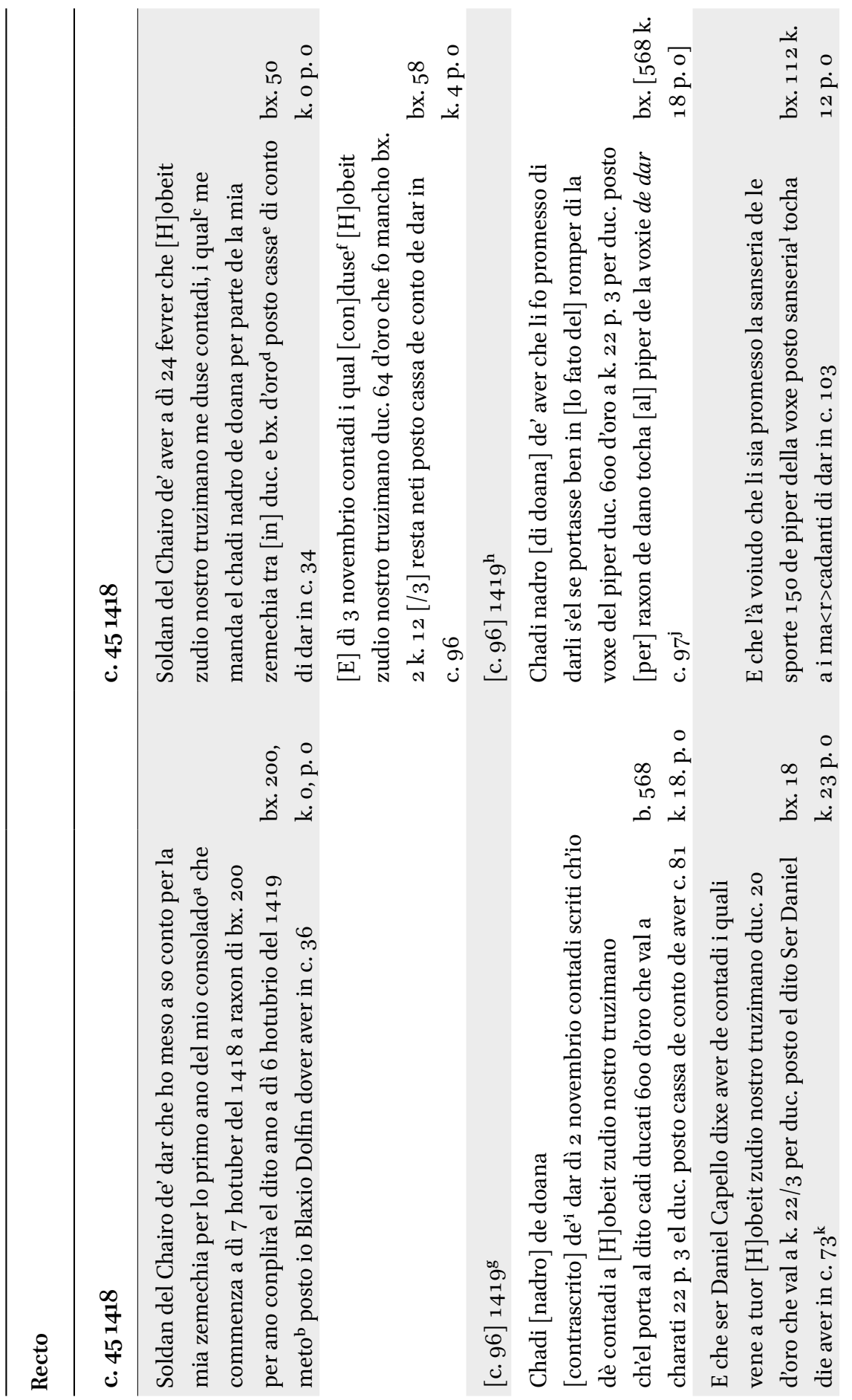



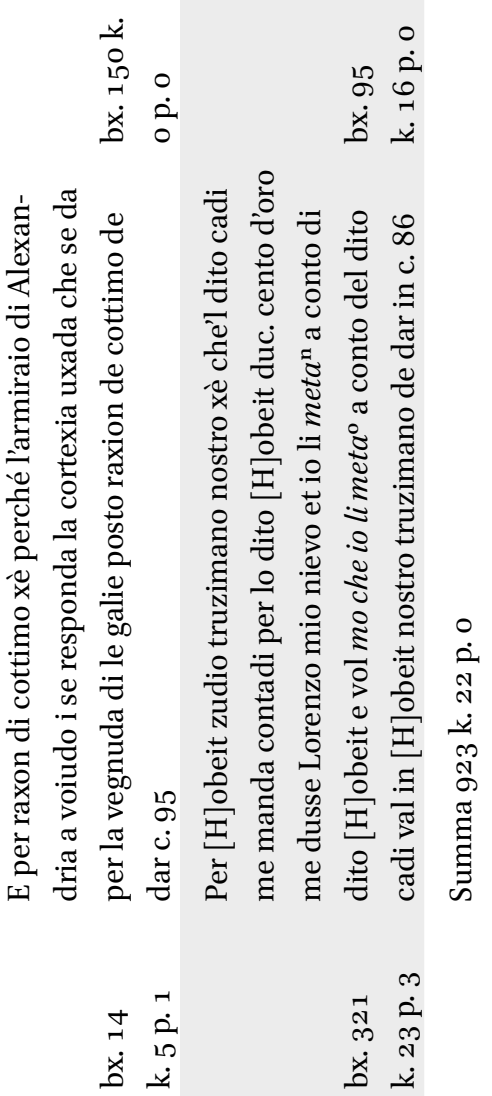

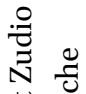

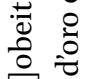

I 105

茎 草

$\frac{7}{0} \stackrel{0}{0}$

:-

$\stackrel{\pi}{ \pm}$ i :

రิن

.$\circ$ คำ

हี Еี

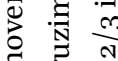

I

$\therefore$ 원

鹀葛

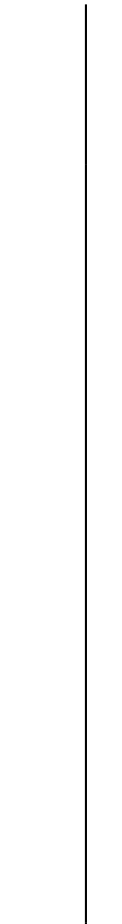

g

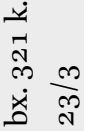

$\begin{array}{ll}m & m \\ & \dot{0} \\ 0 & \dot{x}\end{array}$

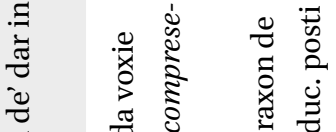

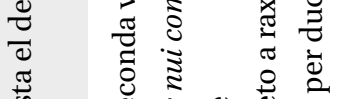

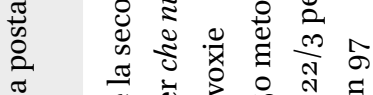

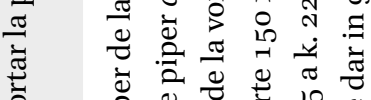

ป

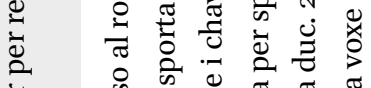

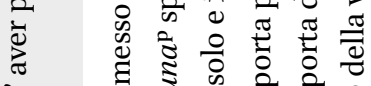

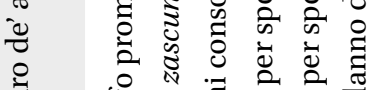

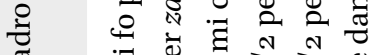

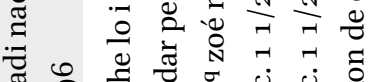

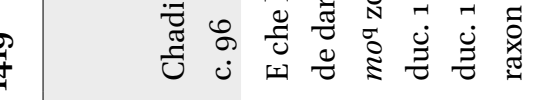

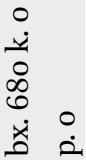

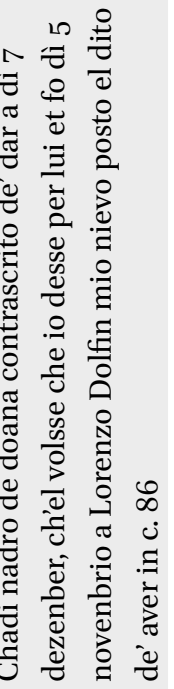




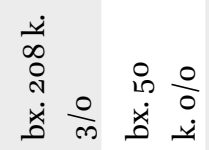

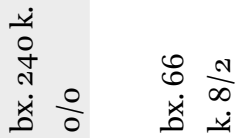

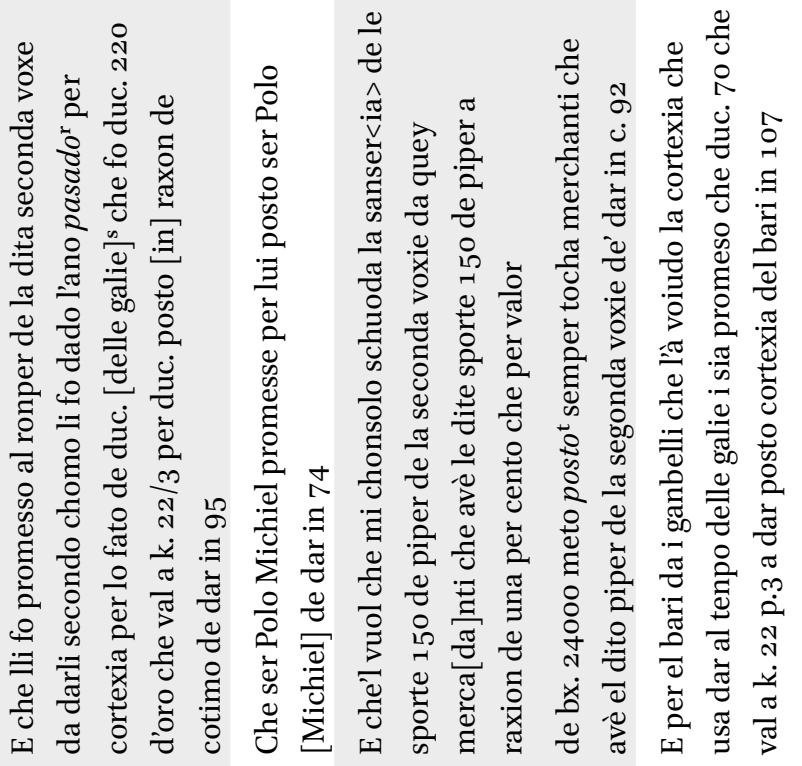




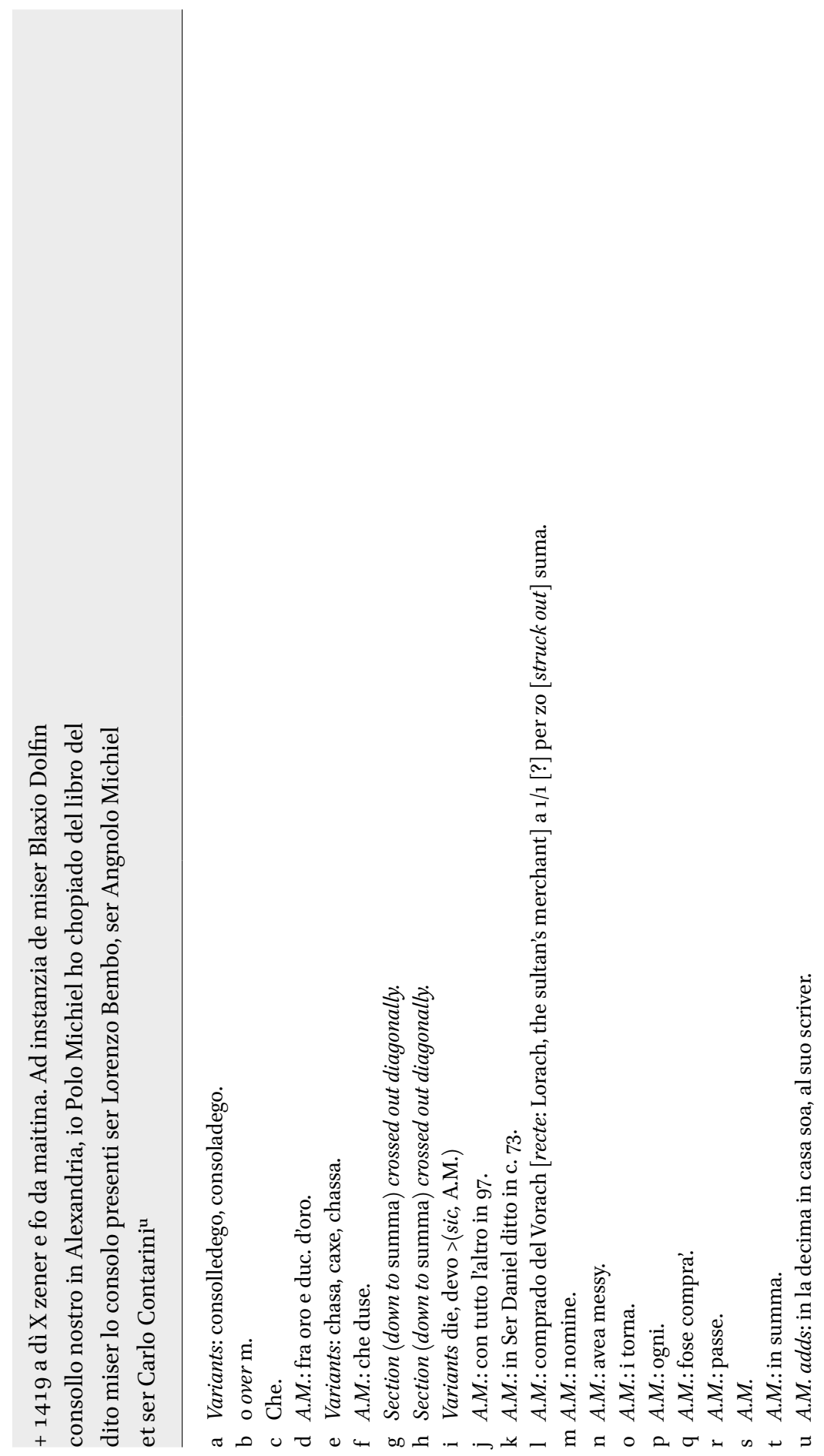




\section{Appendix 2: Partial Reconstruction of the Venetian Consul's Accountancy}

We can distinguish two types of accounts possibly kept in two different ledgers, a ledger for personal accounts (debit receiver, credit giver) and real accounts (chassa de conto, normally called conto di cassa) and some sort of expense account. All amounts in bezants as above.

Personal accounts

Sultan (PA)

$\operatorname{Dr}$ [die dar] $\quad$ Cr [die aver]

50

$200 \quad 58$

Customs inspector (PA)

\begin{tabular}{lc}
\hline Dr [die dar $]$ & Cr [die aver] \\
\hline 568.75 & 568.75 \\
19 & 112.5 \\
14.25 & 150 \\
680 & 95.6 \\
& 213.25 \\
& 208.1 \\
& 50 \\
& 240 \\
& 66.3
\end{tabular}


Biagio Dolfin [Venetian consul] (PA)

$\operatorname{Dr}[$ die dar] $\quad \operatorname{Cr}[$ die aver $]$

200

Obed [Venetian dragoman] (PA)

Dr [die dar] Cr [die aver]

$95.6 \quad 95.6$

Daniel Capello (PA)

Dr [die dar] Cr [die aver]

19

Polo Michiel (PA)

Dr [die dar] $\operatorname{Cr}[$ die aver $]$

50

Lorenzo Dolfin [nephew of B. Dolfin] (PA)

\begin{tabular}{ll}
\hline Dr [die dar $]$ & $\operatorname{Cr}[$ die aver $]$ \\
\hline 680
\end{tabular}


Real account (RA)

$\mathrm{Dr}=$ incomes; $\mathrm{Cr}=$ expenses

Chassa de conto (RA) c. 81, 36, 101, 96...

Dr [die dar] Cr [die aver]

50

$58 \quad 568.75$

$95.6 \quad 14.25$

'Nominal' accounts (NA)

These are not really nominal accounts in the strict English sense of the word but rather akin to expenses and income accounts according to the American accounting standard.

Pepper auction (NA) c. 81, 92, 97

$\operatorname{Dr}$ [expenses] $\operatorname{Cr}$ [incomes]

$568.75 \quad$ Here would figure the payments

213.25 from the merchants (booked via

240 the cash-box account)

Cottimo (NA) c. 95

$\operatorname{Dr}$ [expenses] $\mathrm{Cr}$ [income]

150

208 
Cortesia de bari [compulsory (?) tip for some sort of petty local officials] (NA) c. 107

$\operatorname{Dr}$ [expenses] $\quad \operatorname{Cr}[$ income $]$

66.3

Sanseria [brokerage] (NA) c. 103

$\operatorname{Dr}[$ expenses] $\quad \operatorname{Cr}[$ income $]$

112.5

\section{Bibliography}

\section{Archival Sources}

Archivio di Stato, Venice (ASVe).

Procuratori di San Marco, Commissarie miste, “Commissaria Biagio Dolfin”, b. 181, fasc. xxIII, int. n.

Procuratori di San Marco, Commissarie miste, b. 180, "Comissaria Biagio Dolfin", fasc. III, IX.

\section{Primary Sources (Edited)}

Mas Latrie, Louis Comte de, Traités de paix et de commerce et documents divers concernant les relations des chrétiens avec les Arabes de l'Afrique septentrionale au moyen âge (Paris, 1866, supplement/appendice re Egypt 1872).

Pedani(-Fabris), Maria Pia, "Gli ultimi accordi tra i sultani mamelucchi d'Egitto e la Repubblica di Venezia”, Quaderni di Studi Arabi 12 (1994): 49-64.

Pegolotti, Francesco di Balducci, La pratica della mercatura, Allan Evans, ed. (Cambridge, Mass, 1936).

Sopracasa, Alessio, ed., Venezia e l'Egitto alla fine del medioevo: Le tariffe di Alessandria (Études Alexandrines 29) (Alexandria, 2013).

Tafel, Gottlieb Lucas Friedrich and Georg Martin Thomas, eds., Urkunden zur älteren Handels- und Staatsgeschichte der Republik Venedig mit besonderer Beziehung auf 
Byzanz und die Levante. Vom neunten bis zum Ausgang des fünfzehnten Jahrhunderts (acta, Historische Commission der Kaiserlichen Akademie der Wissenschaften) (Wien, 1856).

Thomas, Georg Martin and Riccardo Predelli, eds., Diplomatarium veneto-levantinum sive acta et diplomata res venetas graecas atque levantis illustrantia a. 1351-1454, pars II (Deputazione veneta di storia patria) (Venezia, 1899).

Thomas, Georg Martin, ed., Diplomatarium veneto levantinum sive acta et diplomata res venetas graecas atque Levantis illustrantia a. 1300-1350 [pars I] (Monumenti storici publicati dalla reale deputazione veneta di storia patria 5) (Venezia, 1880).

Al-Turkumān̄̄, 'Abd Allāh, Kitāb al-Luma' fi-l-hawādith wa-l-bida', Subhi Y. Labīb, ed. (Cairo, 1986).

Venezia -Senato: Deliberazioni miste, vol. 9 registro XXII (1344-1345), Edoardo Demo, ed. (Venezia: Istituto Veneto di Scienze, Lettere ed Arti, 2007).

\section{Secondary Sources}

Adriaenssens, Veerle \& Jo Van Steenbergen, "Mamluk authorities and Anatolian realities: Jānibak al-Ṣūfì, sultan al-Ashraf Barsbāy, and the story of a social network in the Mamluk/Anatolian frontier zone, $1435^{-1438}$, Journal of the Royal Asiatic Society 26/4 (2016): 591-630.

Apellániz Ruiz de Galarreta, Francisco Javier, Pouvoir et finance en Méditerranée prémoderne: Le deuxième état Mamelouk et le commerce des épices (1389-1517) (Barcelone, 2009).

Ashtor, Eliyahu, "Le monopole de Barsbay d'après des sources vénitiennes", Anuario de estudios medievales. Instituto de historia medievale de España 9 (1974-79): 551-572.

Ashtor, Eliyahu, A Social and Economic History of the Near East in the Middle Ages (Berkeley, 1976).

Ashtor, Eliyahu, Levant Trade in the Later Middle Ages (Princeton, N.J., 1983).

Ayalon, David, "The System of Payment in Mamluk Military Society", Journal of the Economic and Social History of the Orient 1 (1958): 37-65, 257-296.

Cahen, Claude, "Douanes et commerce dans les ports méditerranéens de l'Égypte médiévale d'après le Minhadj d'al-Makhzumi”, Journal of the Economic and Social History of the Orient 7 (1964): 217-314.

Christ, Georg, "Masked Cooperation with the Infidel? The Venetian Commercial Privileges, Political Power, and Legal Culture in Mamlûk Egypt", in Ausma Cimdina and Jonathan Osmond, eds., Power and Culture. Hegemony, Interaction and Dissent (Pisa, 2006), pp. 33-51.

Christ, Georg, "Passagers clandestins? Rôle moteur des galères vénitiennes et concurrence des navires ronds à Alexandrie au début $\mathrm{du}_{\mathrm{xv}}^{\mathrm{e}}$ siècle", in Damien Coulon, Dominique Valérian, and Christophe Picard, eds., Espace et réseaux en méditerranée 
médiévale, mise en place des réseaux, les politiques d'état dans la formation des réseaux (Paris, 2010), pp. 275-290.

Christ, Georg, "Filippo di Malerbi — un spécialiste du transfert clandestin en Égypte au début du $15^{\text {ème }}$ siècle", in Daniel König, Rania Abdellatif, Yassir Benhima, and Elisabeth Ruchaud, eds., Acteurs des transferts culturels en Méditerranée médiévale (München, 2012), pp. 100-110.

Christ, Georg, Trading Conflicts. Venetian Merchants and Mamluk Officials in Late Medieval Alexandria (The Medieval Mediterranean 93) (Leiden, 2012).

Christ, Georg, "The Venetian Consul and the Cosmopolitan Mercantile Community of

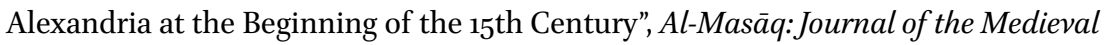
Mediterranean 26/1 (2014): 62-77.

Christ, Georg, "Beyond the Network-Connectors of Networks: Venetian Agents in Cairo and Venetian News Management", in Stephan Conermann, ed., Everything is on the Move: The Mamluk Empire as a Node in (Trans-)Regional Networks (Göttingen, 2014), pp. 27-59.

Christ, Georg, "Kreuzzug und Seeherrschaft. Clemens V., Venedig und das Handelsembargo von 1308", in Nikolas Jaspert and Michael Borgolte, eds., Maritimes Mittelalter: Meere als Kommunikationsräume (Vorträge und Forschungen / Konstanzer Arbeitskreis für mittelalterliche Geschichte 83) (Ostfildern, 2016), pp. 261-282.

Christ, Georg, "Collapse and Continuity: Alexandria as a declining city with a thriving port (13th-16th centuries)", in Wim Blockmans, Mikhail Krom, Justyna WubsMrozewicz, eds., The Routledge Handbook of Maritime Trade Around Europe, 1300-160o: Commercial Networks and Urban Autonomy (London, 2017), pp. 121-140.

Christ, Georg, A King of the Two Seas? Mamluk Trade Policy in the Wake of the Crisis of the Fourteenth Century (Ulrich Haarmann Memorial Lecture vol. 13) (Berlin, 2017).

Christ, Georg, "Non ad caudam sed ad caput invadere: The Sack of Alexandria between Pride, Crusade and Trade Diplomacy $\left(\mathbf{1 3}_{6} 5^{-1370}\right)$ ", in Gherardo Ortalli and Alessio Sopracasa, eds., Rapporti mediterranei, pratiche documentarie, presenze veneziane: Le reti economiche e culturali (XIV-XVI secolo) (Venezia, 2017), pp. 153-182.

Christ, Georg, "The Sultans and the Sea: Mamluk Coastal Defence, Dormant Navy and Delegation of Maritime Policing (14th and Early 15th Centuries)", in Stephan Conermann and Reuven Amitai, eds., The Mamluk Sultanate and its Neighbors: Economic, Social and Cultural Entanglements (Mamluk Studies) (Göttingen, 2019), pp. 215-256.

Dekkiche, Malika, "Le Caire. Carrefour des Ambassades: Étude historique et diplomatique de la correspondance échangée entre les sultans mamlouks circassiens et les souverains timourides et turcomans (Qara Qoyunlu-Qaramanides) au $\mathrm{XV}^{\mathrm{e}} \mathrm{s}$. d'après le ms. ar. 4440 (BnF, Paris)" (PhD thesis Université de Liège, Faculté de Philosophie et Lettres, 2011).

Dekkiche, Malika, "State Recognition in the Service of State Formation? Legitimacy in 15th century Mamluk Egypt", paper presented at the conference Wither the Early Modern State (Ghent, September 2014). 
Deutsches Rechtswörterbuch (http://drw-www.adw.uni-heidelberg.de/drw/).

Diem, Werner, Ehrendes Kleid und ehrendes Wort: Studien zu tašrīf in mamlukischer und vormamlukischer Zeit (Abhandlungen für die Kunde des Morgenlandes 54.2) (Würzburg, 2002).

Drory, Joseph, "Maqrizi in Durar al-'Uqud with regard to Timur Leng", in Urbain Vermeulen et al., eds., Egypt and Syria in the Fatimid, Ayyubid and Mamluk Eras VII. Proceedings of the 16th, 17th and 18th International Colloquium Organized at Ghent University in May 2007, 2008 and 2009 (Orientalia Lovaniensia Analecta 223) (Leuven, 2013), pp. 393-402.

Heffening, Willi, Das islamische Fremdenrecht bis zu den islamisch-fränkischen Staatsverträgen. Eine rechtshistorische Studie zum Figh (Hannover, 1925).

Heyd, Wilhelm, Histoire du commerce du Levant au moyen-âge, vol. 2 (Leipzig: Otto Harrasowitz, 1886).

Hinz, Walther, "Das Rechnungswesen orientalischer Reichsfinanzämter", Der Islam 29 (1950): 1-27, 113-141.

Igarashi, Daisuke, Land Tenure, Fiscal Policy, and Imperial Power in Medieval Syro-Egypt (Chicago: Middle East Documentation Center, 2015).

Jacoby, David, "Le consulat vénitien d'Alexandrie d'après un document inédit de 1284", in Damien Coulon et al., eds., Chemins d'outre-mer. Études d'histoire sur la Méditerranée médiévale offertes à Michel Balard (Byzantina Sorbonensia 20) (Paris, 2004), pp. 461-474.

Jacoby, David, "Les Italiens en Égypte aux XII ${ }^{\mathrm{e}}$ et XIII ${ }^{\mathrm{e}}$ siècle: du comptoir à la colonie?", in Alain Ducellier and Michel Balard, eds., Coloniser au Moyen Âge: Méthodes d'expansion et techniques de domination (Paris, 1995), pp. 76-88.

Khadduri, Majid, “Ṣulh", in Encyclopaedia of Islam, and ed. (Leiden: Brill), s.v.

Labīb, Subhi Yanni, "Iskandariyya”, in Encyclopaedia of Islam, 2nd ed. (Leiden: Brill), s.v.

Labīb, Subhi Yanni, "The Problem of the Bid'a in the Light of an Arabic Manuscript of the Fourteenth Century", Journal of the Economic and Social History of the Orient 7 (1964): 191-196.

Labīb, Subhi Yanni, Handelsgeschichte Ägyptens im Spätmittelalter (1171-1517) (Wiesbaden, 1965).

Lane, Frederic Chapin. "Venture Accounting in Medieval Business Management". Bulletin of the Business Historical Society 29 (1945): 164-172.

Leiser, Gary, "Alexandria (Early Period)", in Encyclopaedia of Islam THREE, online (consulted o1 August 2014), s.v.

Loiseau, Julien, Reconstruire la Maison du sultan: Ruine et recomposition de l'ordre urbain au Caire 1350-1450 (Études urbaines 8, 1) (Cairo, 2010).

Mattingly, Garrett, Renaissance Diplomacy (Baltimore, MD, 1955).

Mayer, Leo Ary, Mamluk Costume: A Survey (Genève, 1952).

Melis, Federigo, Storia della ragioneria. Contributo alla conoscenza e interpretazione delle fonti più significative della storia economica (Bologna, 1950). 
Meloy, John L., Imperial Power and Maritime Trade: Mecca and Cairo in the Later Middle Ages (Chicago: Middle East Documentation Center, 2010).

Monés, Hussain, "Djāmakiyya”, in Encyclopaedia of Islam, 2nd ed. (Leiden: Brill), s.v.

Petry, Carl F., "Robing Ceremonials in Late Mamluk Egypt: Hallowed Traditions, Shifting Protocols", in Stewart Gordon, ed., Robes and Honor: The Medieval World of Investiture (London, 2001), pp. 353-377.

Schmitt, Carl, Völkerrechtliche Grossraumordnung mit Interventionsverbot für raumfremde Mächte: ein Beitrag zum Reichsbegriff im Völkerrecht 3., um ein Kapitel über "Reich und Raum" und mehrere Zusätze erw. Ausg. (Berlin, 1941).

Springberg-Hinsen, Monika, Die Khil'a : Studien zur Geschichte des geschenkten Gewandes im islamischen Kulturkreis (MISK 7) (Würzburg, 200o).

Stillmann, Norman A., "Khil'a", in Encyclopaedia of Islam, 2nd ed. (Leiden: Brill), s.v.

Theunissen, Hans Peter Alexander, "Ottoman Venetian Diplomatics: The 'Ahd-names. The Historical Background and the Development of a Category of PoliticalCommerical Instruments together with an Annotated Edition of a Corpus of Relevant Documents" (PhD thesis Universiteit Utrecht, 1991), published online Arabica I, no. 2 (1998): 1-698, http://www.academia.edu/16485339/ accessed 29/10/2019 14: 47:53.

Vallet, Éric, L'Arabie marchande : état et commerce sous les sultans Rasulides du Yémen (626-858/1229-1454) (Bibliothèque historique des pays d'Islam 1) (Paris, 2010).

Vallet,Éric, “Du système mercantile à l'ordre diplomatique :les ambassades entre Égypte mamlūke et Yémen rasūlide (VII ${ }^{\mathrm{e}}-\mathrm{IX}^{\mathrm{e}} / \mathrm{XIII}{ }^{\mathrm{e}}-\mathrm{XV}^{\mathrm{e}}$ siècle)", in Thierry Kouamé, ed., Les relations diplomatiques au Moyen Âge. Formes et enjeux, XLI ${ }^{e}$ congrès de la SHMESP (Paris, 2011), pp. 269-301, [draft with different pagination on academia.edu].

Vallet, Éric, "La comptabilité d'État en pays d'Islam: normes et formes VII ${ }^{\mathrm{e}}-\mathrm{XV}{ }^{\mathrm{e}}$ siècle", in O. Mattéoni, ed., Classer, dire, compter. Discipline du chiffre et fabrique d'une norme comptable à la fin du Moyen Âge (Paris, 2015), pp. 379-393.

Van Steenbergen, Jo, “Mamlukisation' between Social Theory and Social Practice: An Essay on Reflexivity, State Formation, and the Late Medieval Sultanate of Cairo", ASK Working Paper 22 (2015), https://www.mamluk.uni-bonn.de/publications/ working-paper/ask-wp-22-vansteenbergen.pdf accessed 18.08.2016.

Voigt, Rüdiger, Grossraum-Denken: Carl Schmitts Kategorien der Grossraumordnung (Stuttgart, 2008).

Walker, Bethany J., "Rethinking Mamluk Textiles", Mamlûk Studies Review 4 (2000): 167-217.

Wiet, Gaston, "Les marchands d'épices sous les sultans mamlouks", Cahiers d'Histoire Égytienne 7 (1955): 81-147.

Wing, Patrick, "Submission, Defiance, and the Rules of Politics on the Mamluk Sultanate's Anatolian Frontier", Journal of the Royal Asiatic Society 25/3 (2015): 377-388. 